Check for updates

Montreal

Cite this as: $B M J 2022 ; 376: 0453$ http://dx.doi.org/10.1136/bmj.0453 Published: 22 February 2022

\title{
Covid-19: Mexico City gave ivermectin kits to people with covid in "unethical" experiment
}

\section{Owen Dyer}

The government of Mexico City handed out nearly 200000 "ivermectin based kits" last year to people who had tested positive for covid-19, without telling them they were subjects in an experiment on the drug's effectiveness.

The results of that experiment were then written up by public officials in an article placed on popular US preprint server SocArXiv. ${ }^{1}$ It became one of site's most viewed articles, claiming that ivermectin had reduced hospital admissions by $52-76 \%$.

But those officials have been under fire at home since SocArXiv withdrew the paper earlier this month, calling it "either very poor quality or else deliberately false and misleading."

Opposition deputies in Mexico City’s Congress demanded hearings and said they would bring legal action against the paper's lead author, José Merino, head of the city's Digital Agency for Public Innovation.

Explaining the decision to withdraw the article-the first to be taken down by SocArXiv-the site's steering committee wrote that it had responded "to a community groundswell beseeching us to act" in order "to prevent the paper from causing additional harm."2

The committee wrote, "The paper is spreading misinformation, promoting an unproved medical treatment in the midst of a global pandemic. The paper is part of, and justification for, a government programme that unethically dispenses (or did dispense) unproven medication apparently without proper consent or appropriate ethical protections.”

In addition, the SocArXiv committee noted that "the authors did not properly disclose their conflicts of interest.” Three of the authors later appeared at a press conference with the chief of the Mexico City government, Claudia Sheinbaum, citing the article as evidence of the success of the city's covid policy. ${ }^{3}$

One of these authors was Mexico City's secretary of health, Olivia López Arellano, who is tasked with overseeing the city's covid response. The city officials are political allies of Mexico's president, Andrés Manuel López Obrador, who has frequently flouted public health measures and played down the risk from covid.

While López Obrador is a left wing politician, the Mexico City ivermectin study was widely cited by allies of Brazil's far right president Jair Bolsonaro, another leader who has minimised the pandemic and touted unproven cures.

In response to SocArXiv's withdrawal of their article, Merino, López, and most of the other authors wrote to its director, Philip Cohen, urging him to resign. "We find it extremely unethical, colonialist, and authoritarian that in the absence of a serious argument, you shut a work down based on political motivations due to the current divisions in your own country," they wrote. ${ }^{4}$

But one co-author, data analyst Saúl Caballero, wrote that he applauded and supported SocArXiv's decision to retract the "scientifically false article," adding, "I apologise for any potential harm done." 5

Mexico City's government rules only the inner core of the vast conurbation, with about 9.2 million inhabitants. It has recorded 41902 covid deaths, a higher toll than the national average. Mexico as a whole has 315688 confirmed deaths from covid, and its excess mortality during the pandemic is 460000 .

\section{Arkansas ivermectin experiments draw Tuskegee comparisons}

Four Arkansas jail inmates suffered side effects including vision problems, diarrhoea, and bloody stools after the physician at Washington County jail treated their covid with high doses of ivermectin without their knowledge, according to a lawsuit supported by the American Civil Liberties Union. ${ }^{6}$ The case has prompted media comparisons to the infamous Tuskegee experiment, in which black men in the American South were told they would be treated for syphilis but were actually followed without treatment to study the natural course of the disease.

The four men are suing the jail, the county sheriff Tim Helder, and the jail's physician Robert Karas. Karas often praised ivermectin on Facebook and his private clinic's blog, citing claims made by the Frontline Covid Critical Care Alliance, a group widely blamed for spreading covid misinformation. The US Centers for Disease Control, the Food and Drug Administration, and the National Institutes of Health have all advised against using ivermectin to treat covid.

The inmates were told that their treatment consisted of vitamins, antibiotics, and steroids, according to their court filing. They received ivermectin doses as much as six times higher than that recommended for deworming, the drug's normal use. They only learnt that they had received ivermectin six months later.

"It was not consensual," one of the men, Edrick Floreal-Wooten, told CBS News. "They used us as an experiment-like we're livestock.”

Merino J, Borja VH, Lopez O, etal. Ivermectin and the odds of hospitalization due to covid-19: evidence from a quasi-experimental analysis based on a public intervention in Mexico City (Withdrawn).https://osf.io/preprints/socarxiv/r93g4/doi: 10.31235/osf.io/r93g4 
2 Cohen PN. SocArXiv Steering Committee. On withdrawing "Ivermectin and the odds of hospitalization due to COVID-19," by Merino et al. SocArXiv. 4 February 2022. https://socopen.org/2022/02/04/on-withdrawing-ivermectin-and-the-odds-of-hospitalization-due-to-covid19-by-merino-et-al/

3 Videoconferencia de prensa, Jefa de Gobierno. 14 May 2021. www.youtube.com/watch?v=hrTVnjOMDjU.

4 Merino J, Borja VH, Lopez O, etal. Letter toSocArXiv. 4 February 2022. https://twitter.com/PPmerino/status/1489734477442019330.

5 Caballero S. Statement regardingSocArXiv. 7 February 2022. https://twitter.com/nasaul/status/1490785126749454338.

6 Floreal-Wooten, Little, Gonzales, Blackburn v Washington County Detention Center, Sherrif Tim Helder, Dr Robert Karas and others. US District Court, Western District Of Arkansas, Case 5:22-cv-05011-TLB-CDC. www.acluarkansas.org/sites/default/files/field_documents/complaintfile_marked.pdf.

This article is made freely available for personal use in accordance with BMJ's website terms and conditions for the duration of the covid-19 pandemic or until otherwise determined by BMJ. You may download and print the article for any lawful, non-commercial purpose (including text and data mining) provided that all copyright notices and trade marks are retained. 